Japanese Journal of Transfusion Medicine, Vol. 37. No. 4 37(4) : 528-530, 1991

症

例

抗 $\mathrm{Jr}$ 抗体による遅延性輸血反応の 1 症例

吉田 久博 万木紀美子 伊藤 和彦
京都大学医学部附属病院輸血部

(平成 3 年 4 月 17 日受付)

\title{
A CASE OF DELAYED HEMOLYTIC TRANSFUSION REACTION DUE TO ANTI-Jr ${ }^{a}$
}

\author{
Hisahiro Yoshida, Kimiko Yurugi and Kazuhiko Ito \\ Department of Transfusion Medicine, Kyoto University Hospital, Faculty of Medicine, \\ Kyoto University, Kyoto 606, Japan
}

We observed a case with delayed hemolytic transfusion reaction due to anti-Jr ${ }^{\mathrm{a}}$ which had not been detected in her pretransfusion serum. She was transfused with 4 units of blood, which was judged to be compatible with crossmatch test. The immediate posttransfusion period was uneventful. Three days later, she developed a slight fever and hypertension with decreasing blood level, but these symptoms disappeared without special treatment after several hours. Anti-Jra could be identified in both her serum and the eluate from her red cells 8 days after transfusion. Anti-Jra in the serum gradualy decreased with its half life of about 20 days.

\section{緒 言}

$\mathrm{Jr}^{a}$ 抗原は Stroup \& MacIlroyにより1970年に 初めて報告された抗原である11.Jra陰性者は東洋 人に特異的に見いだされる血液型で, 中島らの調 查によると,その陰性頻度は約 3,000 人に 1 人の割 合, 即ち, $0.03 \%$ と報告されている ${ }^{2)}$. 抗 $\mathrm{Jr}^{a}$ 抗体 は間接抗グロブリン試験によって検出される抗体 で，抗原陽性血球の酵素処理の有無にかかわらず 同等の反応性を示すことが知られている3). また, 現在日本で登録されている $\mathrm{Jr}(\mathrm{a}-)$ の供血者は主 に経産婦によって占められていることから, 妊娠 によって容易に抗体産生されるものと推察されて いる ${ }^{4}$. 抗 $\mathrm{Jr}^{a}$ 抗体を有する患者に $\mathrm{Jr}^{a}$ 抗原陽性血 球を輸血した場合，一般に無症状のまま経過する こと, $\mathrm{Jr}^{a}$ 不適合妊娠に损いて大半の症例が重篤な 新生児溶血性反応を示さないことから ${ }^{5)}$, 臨床上 あまり意義のない抗体と考兄られている。しかし， 数千倍の高力価抗体を有する患者においても同様 に無症状のまま経過するか否か明確でなく，また 抗 $\mathrm{Jr}^{a}$ 抗体による遅発性輸血副作用についてほと んど報告されていない.今回, 著者らは高力価抗
$\mathrm{Jr}^{a}$ 抗体により遅発性輸血反応を呈したと考えら れる症例を経験したので報告する。

\section{症例}

K.K., 56歳，女性。過去に 2 度出産歷があり， 輸血歴はない. 1990年 7 月頃より肩こり, 倦怠感, ならびに燕下時不快感があったため，針尒医を受 診。加療するも改善の傾向なく, 食物摂取時の與葆 下痛が光進したことから，同年 8 月末本院外来を 受診. 精査の結果, 頝部食道ガンと診断され， 9 月末腫瘍組織摘除のため本院に入院.

手術に先立ち輸血前検查を行った結果, 患者の 血液型は $\mathrm{AB}$ 型, $\mathrm{Rho}(+)$ で, 直接抗グロブリン 試験は陰性, 不規則抗体検査は陰性であった。 日 赤血液センターより供給された保存血 2 単位およ び濃厚赤血球 8 単位と患者検体との交差試験をア ルブミン・抗グロブリン法により実施した結果, 全て適合と判定された。11月 2 日, 適合血用意の もと手術が開始された。術中保存血, 濃厚赤血球 各 2 単位が輸血されたが, 特に異常は認められず, 手術開始13時間後, 無事摘除術は終了した. 術後 血圧の上昇が認められたため, 降圧剂を投与して 


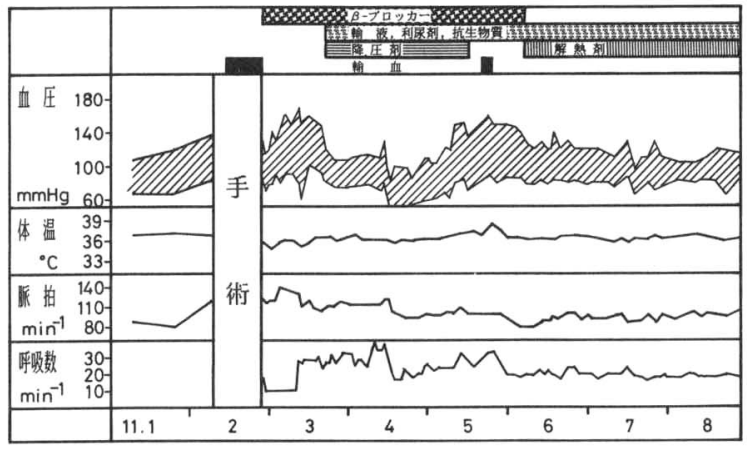

図 1 臨床経過

コントロールしていたが, 術後 3 日目より緩やか な血圧上昇並びに呼吸数の増加が観察された（図 1)。末た血球減少に伴い輸血を実施したが，この 際血圧，体温，呼吸数に僅かな一過性上昇が認め られた。しかしその後臨床諸症状に変化は見られ ず，術後34日目に無事退院した（図 1 ）。

\section{検查成績}

患者の手術前後の各種検査成績を図 $2 \sim 4$ 亿示 した。

1. 輸血検査

直接抗グロブリン試験は術後 3 日目まで陰性で あったが，8日目に陽性反応を示し，以後除々に 減弱し, 1 力月後陰性となった。一方, 抗ヒト補 体血清に対する反応は全て陰性となった。解離液 $\left(\right.$ Rubin 法 $^{6)}$ ) ならびに血清中の不規則抗体につい て精查した結果, 抗 $\mathrm{Jr}^{a}$ 抗体が検出された。血清中 の抗体価は輸血前 $1 / 8$ 倍, 輸血 3 日後 $1 / 2$ 倍, 8 日 後 2,048 倍で, 以後除々に漸减し 3 力月後に 512 倍, 5 カ月後に 128 倍に低下した. IgGサブクラスは IgG 2が主であり IgG 3は検出されなかった。また 解離液中の抗体価以副作用発現以降 1 力月間注注 一定していた。尚, 全輸血製剂の $\mathrm{Jr}^{a}$ 抗原の有無に ついて精査した結果, 全て陽性となり, 交差試験 不適合と判定された（図2）。

\section{2. 生化学検査}

GOT, GPT, LDH は術後上昇した後, 3 日目 より徐々に低下した。 ハプトグロビンは術後減少 し, 約 3 週間低值を維持した後, 1 カ月後に輸血 レベルに回復した（図 3 ).

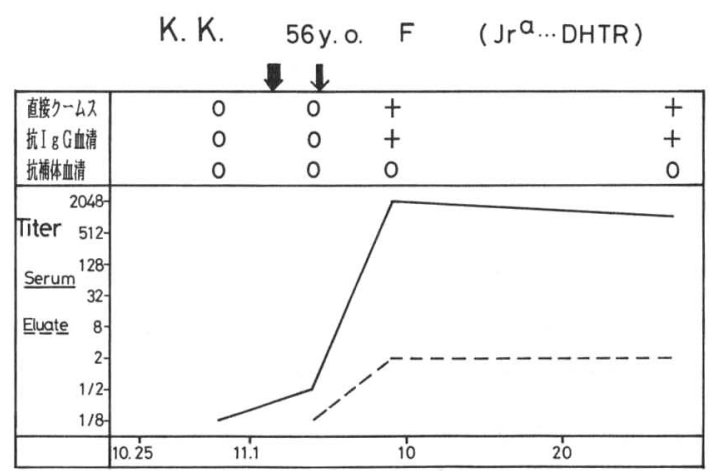

図 2 輸血検査成績
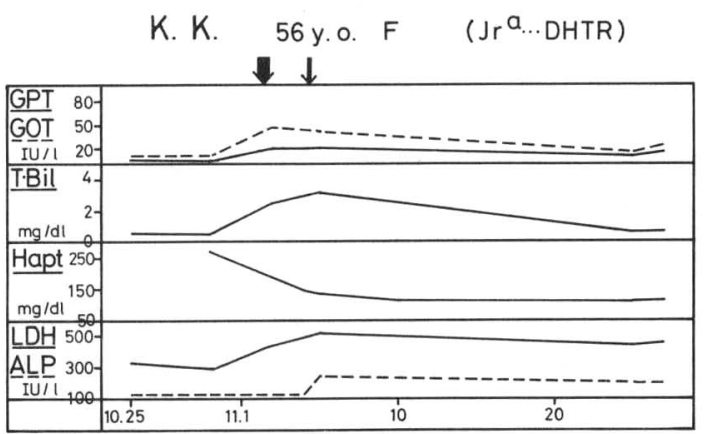

図 3 生化学検查成績

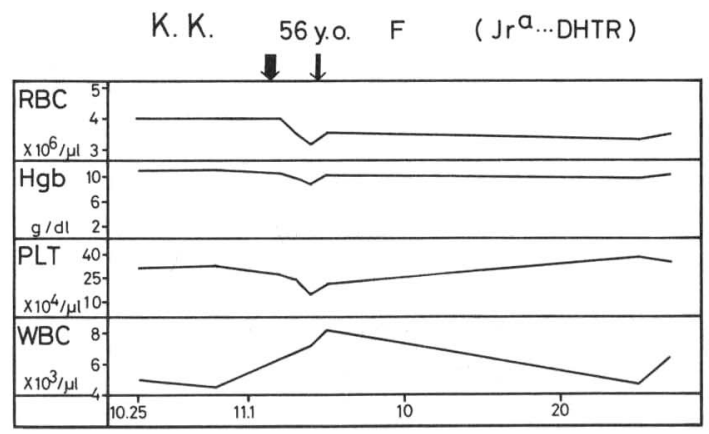

図 4 血液検查成績

3. 血液検查

術後創部からの微量出血ならびに血管外溶血に よると思われる緩やかな赤血球減少が観察された が，4日目以降著明な赤血球減少は認められな かった。 また血小板数は術後一過性に減少し, 白 血球数は増加したが，日を追うに従い徐々に正常 レベルに戻っていった（図4). 


\section{考察}

抗 $\mathrm{Jr}^{a}$ 抗体を有する患者への不適合輸血につい ては現在までに多数報告されており，その大半が 無症状のまま経過することが知られている377)。し かし一部の研究者は, $\mathrm{Jr}^{a}$ 不適合輸血により輸血副 作用を呈する例があること，またその時の赤血球 の生体内寿命が著明に短縮される(半減期約 80 分) ことを報告している ${ }^{8)}$. 本症例では輸血 3 日目に 赤血球レベルの著明な低下が観察されたが, 患者 の体循環血液量から換算して約 $170 \mathrm{~m} l$ の赤血球 が血管系から消失したものと推察される.しかし， その後 $\mathrm{Jr}$ 陽性血球を輸血したにも拘わらず著明 な血球减少の観察されないこと，また輸血副作用 発現時期と抗体価推移との間に少し時間的なずれ のあることが認められた。これは，(1) 輸血した 赤血球製剂の抗原性に差があり抗原性の強い血球 のみ破壊されたため，(2) 抗原刺激によって抗 $\mathrm{Jr}^{a}$ 抗体が増産され始めた初期過程にのみ抗原陽 性血球の破壊が六進したため，あるいはまた，(3) 抗体産生経過中に IgG サブクラスが補体結合性 のないIgG 2に変化したためではないかと推察さ れる.

$\mathrm{Jr}^{a}$ の陰性頻度は報告者により異なっている が2)4, 当院では最近 3 年間で 3 件の $\mathrm{Jr}^{a}$ 陰性者を 見出している。これは1,900名に 1 名の割合である が，これらの患者は全て経産婦で占められている ことから，25歳以上の女性患者を対象にその頻度 を求めると，840名に 1 名， $0.12 \%$ となる。この值 は大久保の成績4) と非常に近似して抒り，Nakajima らの報告値 ${ }^{2}$ は少し低いよらに思われる。

\section{結語}

抗 $\mathrm{Jr}^{a}$ 抗体により遅発性輸血反応を呈した症例 を経験した。本症例は抗体価が2,048倍と高く不適 合輸血後著明な血球減少值を示したにも拘わら ず，臨床諸症状に僅かな変化を示すのみであった ことから, 遅発性輸血副作用に対する抗 $\mathrm{Jr}^{a}$ 抗体 の臨床的意義は低いものと判断される.

\section{文献}

1) Stroup, M. and Macllroy, M.: Five examples of an antibody defining an antigen of high frequency in the Caucasian population. Program 23rd Annual Meeting of AABB, San Francisco, p86, 1970.

2) Nakajima, H. and Ito, K.: An example of anti-Jra causing hemolytic disease of the newborn and frequency of $\mathrm{Jr}^{\mathrm{a}}$ antigen in the Japanese population. Vox Sang, 35 : 265-267, 1978.

3) Issitt, P.D.: Applied Blood Group Serology, 3rd ed., Montgomery Scientific Publications, Florida, p404-405, 1985.

4）大久保康人：日本人の稀な血液型の表現型 $\mathrm{Fy}(\mathrm{a}-$ ), Di(b-), Jr(a-)について．血液事業, 1:279-284, 1978.

5) 浮田昌彦, 渡辺幸子, 渡辺文江, 内山英一, 直木 恭子： $\mathrm{Jr}^{\mathrm{a}}$ 不適合妊娠における抗 $\mathrm{Jr}$ 抗体の胎児・ 新生児への影響. 日輸血会誌, $34: 636-641,1988$.

6) Rubin, H.: Antibody elution from red blood cells. J. Clin. Pathol., 16 : 70-73, 1963.

7) Azar, P.M., Kitagawa, H., Fukunishi, A., Yasuda, T., Oki, M., Saji, H., Tanioka, K. and Hosoi, T.: Uneventful transfusion of $\operatorname{Jr}(\mathrm{a}+$ ) red cells in the presence of anti-Jra. Jap. J. Transf. Med., 34 : 406-410, 1988.

8) Kendall, A.G.: Clinical importance of the rare erythrocyte antibody anti-Jra ${ }^{\mathrm{a}}$. Transfusion, 16 : 646-647, 1976. 